\title{
PENERAPAN METODE BERMAIN PERAN PADA PEMBELAJARAN BAHASA INDONESIA MATERI FABEL DI KELAS VII 4 SMP NEGERI 2 SINGARAJA
}

\author{
Luh Pande Ayu Swadayani ${ }^{1}$, I Made Sutama ${ }^{2}$, Gede Gunatama ${ }^{3}$ \\ Jurusan Pendidikan Bahasa dan Sastra Indonesia \\ Fakultas Bahasa dan Seni \\ Universitas Pendidikan Ganesha \\ Singaraja, Indonesia \\ email: $\left\{\begin{array}{c}\text { ayuotelow@gmail.com, imadesutamaubd@gmail.com, } \\ \text { gedegunatama22@gmail.com\} }\end{array}\right.$
}

\begin{abstract}
ABSTRAK
Penelitian ini bertujuan untuk mengkaji pembelajaran teks fabel siswa kelas VII 4 SMP Negeri 2 Singaraja dengan penerapan metode bermain peran yang meliputi aspek penerapan, respons, dan kendala-kendala yang dihadapi oleh guru bahasa Indonesia di SMP Negeri 2 Singaraja. Rancangan penelitian ini adalah deskriptif-kualitatif dan kuantitatif. Subjek penelitian ini adalah guru bahasa Indonesia dan siswa kelas VII 4 SMP Negeri 2 Singaraja. Objek penelitian ini adalah penerapan , respons, dan kendala-kendala penerapan metode bermain peran dalam pembelajaran teks fabel. Data yang diperoleh dikumpulkan dengan beberapa metode yakni: (1) metode observasi untuk mengamati proses pembelajaran berdasarkan aktivitas guru dan siswa selama belajar dengan metode bermain peran, (2) metode dokumentasi untuk mengumpulkan data berkaitan dengan keterampilan siswa memerankan teks fabel berdasarkan metode bermain peran, (3) metode wawancara untuk mengetahui kendala-kendala yang dihadapi guru saat pembelajaran teks fabel siswa kelas VII 4 SMP Negeri 2 Singaraja dengan penerapan metode bermain peran,dan (4) metode kuisioner untuk mengetahui respons siswa dalam menggunakan metode bermain peran. Data observasi dan wawancara dianalisis dengan teknik deskriptif kualitatif,sedangkan data hasil angket kuisioner dengan teknik deskriptif kuantitatif. Berdasarkan analisis data ditemukan bahwa (1) penerapan metode bermain peran pada pembelajaran bahasa indonesia materi fabel kelas VII 4 SMP Negeri 2 Singaraja berlangsung dengan baik, (2) respons siswa terhadap penerapan metode bermain peran di kelas VII 4 SMP Negeri 2 Singaraja sangat positif $(27,73)$ dan, (3) kendala-kendala guru dalam penerapan metode bermain peran pada pembelajaran bahasa indonesia kelas VII 4 SMP Negeri 2 Singaraja ialah yang pertama kurangnya kesiapan siswa kurang, pembelajaran yang membosankan, kurangnya motivasi guru terhadap siswa.
\end{abstract}

Kata kunci: bermain peran, pembelajaran, teks fabel

\begin{abstract}
This research has purpose to investigate the fable text of the fourth grade students at SMP Negeri 2 Singaraja in applying the role play method which consists of some aspects such as the application, responses, and some problems which are faced by the Indonesian teacher at SMP Negeri 2 Singaraja. The research designs are descriptive-qualitative and quantitative. The subjects of the study are the Indonesian teacher and the fourth grade students at SMP Negeri 2 Singaraja. The objects of the study are the application, responses, and some problems in applying the role play in the fable text material. The data which are got were collected in some methods, such as: (1) observation method to observe the learning process based on the teacher activity and the students during the learning in the role play, (2) the documentation method to collect the data which are related to the students' skill in playing the fable
\end{abstract}


text based on the role play method, (3) the interview method to know some problems which are faced by the teacher in teaching the fable text of the fourth grade students at SMP Negeri 2 Singaraja in applying the role play method, and (4) the questionnaire method to know the responses of the students in using the role play method. The observation data and interview are analyzed in the descriptive-qualitative technique, while the result of the quetionnaire is analyzed in the descriptive-quantitative technique. Based on the data analysis, it was found that (1) in applying the role play method of the fable text in the Indonesian subject, it can be done well, (2) the responses of the students in applying the role play method of the fourth grade students at SMP Negeri 2 Singaraja is very positive $(27,73)$, and (3) the problems of the teacher in applying the role play method in Indonesian subject at the fourth grade students at SMP Negeri 2 Singaraja are, the first is the low of readiness of the students, the second is the learning which is boring, and the last is the low motivation of the teacher to the students.

Key words: role play, learning, the fable text

\section{PENDAHULUAN}

Belajar adalah suatu kata yang sudah cukup akrab dengan semua lapisan masyarakat. menurut Djamarah (2008) belajar adalah serangkaian kegiatan jiwa raga untuk memperoleh suatu perubahan tingkah laku sebagai hasil dari pengalaman individu dalam interaksi dengan lingkungannya yang menyangkut kognitif,afektif, dan psikomotor. Belajar pada intinya adalah proses memeroleh berbagai pengetahuan(kognitif), keterampilan (psikomotorik), dan sikap (afektif). Proses belajar ini dapat terjadi di sekolah dan di luar sekolah. Sebagai salah satu lembaga yang menyelenggrakan pendidikan formal, sekolah mempunyai peranan penting dalam mendewasakan peserta didik agar menjadi masyarakat yang berguna.

Dalam Kurikulum 2013 perencanaan pembelajaran diwujudkan dengan kegiatan penyusun rancangan pembelajaran (RPP). RPP merupakan rancangan pembelajaran yang dikembangkan secara rinci mengacu pada silabus, buku teks pelajaran. Dalam RPP Kurikulum 2013 termuat berbagai komponen seperti (1) Identitas sekolah, (2) mata pelajaran, dan (3) kelas/semester, (4) materi pokok, (5) Alokasi waktu, (6) Tujuan (7)KD dan indikator pencapaian kompetensi, (8) Materi pelajaran, (9) metode pelajaran, (10) media, (11)sumber, (12) Penilaian. Penelitian ini mengacu pada KD memainkan peran isi fabel dimana siswa akan memainkan peran sesuai dengan isi fabel tersebut.

Permasalahan terkait dengan KD tersebut terlihat banyak siswa yang kurang antusias dalam mengikuti pelajaran. Untuk menghadirkan suasana belajar yang lebih menyenangkan bagi peserta didik maka guru harus mengetahui cara-cara atau metode yang baik diterapkan sehingga siswa termotivasi untuk mengikuti kegiatan pembelajaran. Kegiatan pembelajaran sebaiknya diarahkan kepada kegiatankegiatan yang mendorong siswa belajar aktif baik secara fisik, sosial maupun psikis dalam memahami konsep. Dalam proses pembelajaran hendaknya guru menggunakan metode yang membuat siswa banyak beraktivitas. Metode ini bertujuan untuk memotivasi siswa menarik minat dan perhatian siswa, memberikan kesempatan kepada siswa untuk mengeksplorasi situasi saat mengalami emosi, perbedaan pendapat, dan permasalahan dalam lingkungan hidup social anak, menarik siswa untuk bertanya, mengembangkan kemampuan komunikasi siswa, dan melatih siswa untuk berperan aktif dalam kehidupan nyata.

Bermain peran adalah metode pembelajaran melalui pengembangan imajinasi dan penghayatan anak didik dengan cara anak didik memerankan suatu tokoh baik tokoh hidup atau tokoh mati. Melalui bermain peran siswa mencoba mengeksplorasi hubungan, perasaan, sikap, nilai, dan berbagai strategi pemecahan masalah antar manusia dengan memperagakan dan mendiskusikannya. Metode bermain peran ini di dalamnya menampakkan adanya perilaku pura-pura dari siswa yang terlibat atau peniruan situasi dari tokoh-tokoh sejarah sedemikian rupa. Dengan demikian, metode bermain 
peran adalah metode yang melibatkan siswa untuk berpura-pura memainkan peran/tokoh yang terlibat dalam proses sejarah atau perilaku masyarakat misalnya bagaimana menggugah masyarakat untuk menjaga keberhasilan lingkungan, dan lain sebagainya.

Kelebihan-kelebihan penerapan

metode bermain peran, yaitu (1) membandingkan dan mengkontraskan posisi-posisi yang diambil dalam pokok permasalahan, (2) menerapkan pengetahuan pada pemecahan masalah, (3) melibatkan peserta didik dalam pembelajaran yang langsung, (5) mendorong peserta didik memanipulasi pengetahuan dalam cara yang dinamik, dan (6) mengembangkan pemahaman yang empatik (Zaini, 2008:136). Adapula keunggulan metode bermain peran, yaitu: (1) peran yang ditampilkan menarik akan mendapat respons dari peserta didik lainnya, (2) teknik ini dapat dugunakan dalam kelompok besar maupun kecil, (3) membantu peserta didik memahami pengalaman orang lain yang melakukan peran, (4) membantu peserta didik memahami situasi serta memikirkan masalah yang terjadi dalam bermain peran, dan (5) membutuhkan rasa kemampuan dan kepercayaan diri peserta didik untuk berperan dalam menghadapi masalah.

Tujuan penelitian ini adalah (1) mendeskripsikan penerapan metode bermain peran paa pembelajaran bahasa indonesia kelas VII 4 SMP negeri 2 singaraja, (2) mendeskripsikan respons siswa terhadap metode bermain peran pada pembelajaran bahasa indonesia materi fabel di Kelas VII 4 SMP Negeri 2 Singaraja, (3) mendeskripsikan kendala guru dalam penerapan metode bermain peran.

Hasil penelitian ini diharapkan dapat memberikan manfaat bagi beberapa pihak, baik secara teoretis maupun praktis. Secara teoretis, hasil penelitian ini diharapkan mampu memberikan sumbangan konseptual yang edukatif pada pendidikan bahasa, khususnya pada penggunaan metode bermain peran dalam pembelajaran fabel. Selain itu, penelitian ini juga dapat memberikan informasi sekaligus sumbangan untuk memperluas teori tentang metode bermain peran dalam pembelajaran fabel. Secara praktis, penelitian ini akan memberikan manfaat bagi beberapa pihak, yaitu (1) bagi guru atau pengajar Bahasa dan Sastra Indonesia, termasuk bagi peneliti sendiri sebagai calon guru Bahasa dan Sastra Indonesia, hasil penelitian ini diharapkan dapat memperkaya bahan ajar ataupun memperkaya wawasan pengajar dalam pembelajaran fabel. (2) bagi siswa, penelitian ini dapat menjadi pedoman dalam pembelajaran Bahasa Indonesia, khususnya pembelajaran fabel. (3) bagi sekolah, hasil penelitian ini dapat dijadikan informasi tindak lanjut terhadap metode pembelajaran di kelas agar lebih inovatif dan kreatif, yang dilaksanakan tidak hanya oleh guru Bahasa Indonesia tetapi guru mata pelajaran yang lain. (4) bagi peneliti lain, hasil penelitian ini dapat dimanfaatkan untuk bahan perbandingan atau referensi ketika melakukan penelitian sejenis.

\section{METODE PENELITIAN}

Rancangan penelitian yang digunakan dalam penelitian ini adalah rancangan deskriptif kualitatif. Penelitian ini diharapkan mampu mendeskripsikan pembelajaran teks fabel siswa kelas VII 4 SMP Negeri 2 Singaraja dengan penerapan metode bermain peran.

Subjek penelitian, dalam penelitian ini adalah siswa kelas VII 4 dan guru mata pelajaran Bahasa Indonesia yakni Made Ratna Pratiwi, S.Pd. Menurut Arikunto (1998) subjek penelitian adalah benda, hal atau, orang tempat data untuk variabel melekat, dan yang dipermasalahkan.

Dalam penelitian ini, peneliti menggunakan metode observasi nonpartisipasi, instrumen yang digunakan adalah pedoman observasi. Peneliti juga menggunakan metode wawancara, instrumen yang digunakan adalah pedoman wawancara, metode dokumentasi, instrument pedoman dokumentasi dan metode kuisioner intrumen yang digunakan ialah Angket.

Selanjutnya, data dalam penelitian ini dianalisis secara deskriptif kualitatif dengan 
terdiri atas reduksi data, penyajian data, dan penarikan simpulan. Hasil akhir nanti diperoleh informasi mengenai pembelajaran teks fabel metode bermain peran siswa kelas SMP Negeri 2 Singaraja.

\section{HASIL DAN PEMBAHASAN}

Hasil penelitian mencakup tiga hal, yaitu (1) Penerapan Metode Bermain Peran pada Pembelajaran Bahasa Indonesia Materi Fabel kelas VII 4 SMPN 2 Singaraja, (2) respons siswa terhadap penerapan Metode Bermain Peran pada Pembelajaran Bahasa Indonesia Materi Fabel di kelas VII 4, (3) kendala guru dalam Penerapan Metode Bermain Peran pada Pembelajaran Bahasa Indonesia Materi Fabel Di Kelas VII 4. Pada penelitian ini, pengumpulan data dilakukan melalui metode observasi, metode wawancara, dan metode dokumentasi. Data hasil penelitian mengenai pembelajaran fabel dengan Metode Bermain Peran akan dijabarkan sebagai berikut.

\section{Hasil observasi Pertemuan Pertama}

Observasi pertama di kelas VII 4 dilakukan pada tanggal 3 april 2018. Tepat pukul 15.00 wita bel berbunyi dua kali tanda jam pelajaran akan dimulai. Ketika guru dan peneliti memasuki kelas, ruang kelas tampak tenang. Mereka serentak menyampaikan salam pangganjali umat "Om Swastyastu yang dipimpin oleh ketua kelas. Guru dan peneliti membalas salam mereka. Seluruh siswa tampak siap dengan buku catatan, buku paket, dan alat tulis di atas meja masing-masing. Sebelum pembelajaran dimulai, guru memperkenalkan peneliti kepada siswa bahwa peneliti sedang melaksanakana penelitian di kelas tersebut dan guru mempersilahkan duduk dan mempersiapkan lembar observasi kegiatan guru dan siswa.

Selanjutnya, guru mengecek kehadiran siswa. Saat itu, seluruh siswa hadir. Guru menanyakan kesiapan siswa dalam mengikuti pelajaran dan siswa pun serentak menjawab siap. Setelah siswa dalam keadaan siap menerima pembelajaran, guru pun membuka pelajaran dengan memberikan apersepsi kepada siswa. Bentuk apersepsi yang diberikan guru berupa pertanyaan pancingan yang terkait dengan materi pembelajaran yang akan dipelajari siswa itu Fabel. Guru menanyakan kepada siswa,"Apakah siswa pernah mendengar Fabel." dan menanyakan kepada siswa, "Cerita apa saja yang kalian ketahui", Sebagian besar siswa menjawab pernah mendengar cerita Si kancil. Setelah itu guru menjelaskan pengertian Fabel.

Setelah memberikan apersepsi, guru menyampaikan indikator pembelajaran yang akan dilaksanakan. Indikator yang ingin dicapai pada pembelajaran yang akan dilaksanakan yaitu (1) mengurutkan isi cerita fabel dan, (2) menceritakan kembali isi fabel secara lisan. Pembelajaran pun memasuki kegiatan inti. Guru mulai bertanya kepada siswa terkait pengetahuan awal siswa mengenai fabel. Guru mulai bertanya tentang pengertian Fabel. Beberapa siswa nampak mengangkat tangan. Seorang siswa yang bernama Rizky menjawab dengan cukup benar walau belum sempurna yaitu "Fabel adalah cerita binatang". Guru pun melengkapi jawaban siswa dengan jawaban seperti ini Fabel adalah "Cerita Fiksi atau Khayalan yang mengandung pesan moral." Setelah siswa mulai mengingat kembali pengetahuannya tentang pengertian fabel,pada kegiatan ini guru menyampaikan lebih jelas mengenai pengertian fabel, jenisjenis fabel. Selanjutnya guru memberikan kesempatan kepada siswa untuk bertanya terkait penjelasan yang belum dipahami. Tidak ada satu pun siswa mengacungkan tangan. Melihat keadaan demikian, guru pun bertanya kepada siswa apakah semua sudah paham dan siswa serentak menjawab sudah paham. Selanjutnya guru menjelaskan cara memainkan peran dalam cerita fabel, dan mencontohkan kepada murid menjadi tokoh orang jahat dan baik. Lalu, guru menyuruh beberapa siswa untuk ke depan mempraktekkan menjadi orang jahat dan baik. Waktu itu Rizky tampak memainkan peran orang jahat ke depan kelas dengan sangat bagus. Setelah usai, guru menyuruh siswa membentuk kelompok dengan anggota 5 orang. Guru 
dapat melatih keterampilan berbicara peserta didik melalui cerita teks fabel caranya yaitu guru terlebih dahulu memberikan contoh bercerita di hadapan peserta didik diminta untuk memerhatikan dan menyimak dengan baik. Langkah berikutnya, guru dapat memberikan tugas kepada peserta didik untuk menampilkan cerita yang ada di Buku yang berjudul "Semua Istimewa"lalu guru menyuruh siswa mempelajari teks fabel tersebut dan akan tampil di pertemuan berikutnya.

Guru mengacak dalam memilih kelompok dengan cara menghitung dari meja pojok kanan belakang. Setelah guru menjelaskan guru mempersilahkan siswa lain untuk menanyakan hal-hal yang belum di pahami, sebagian siswa tampak paham sehingga tidak ada yang bertanya.

Dengan demikian, guru mengakhiri pelajaran dengan menugaskan siswa untuk mempelajari kembali materi yang telah di bahas hari itu. Ketua kelas berdiri dan memberikan komando kepada temantemannya untuk mengucapkan paramasantih, "Om Santih, Santih, Santih, Omn"ucap guru dan siswa bersama-sama.

\section{Pertemuan kedua}

Observasi kedua dilakanakan pada kamis, 5 April 2018. Pelajaran bahasa Indonesia berlangsung pada jam ke-3 dan ke-4, pukul 09.00 s.d. 10.45. Saat guru dan peneliti memasuki kelas, situasi kelas tampak tenang. Kesiapan siswa mengikuti pelajaran terlihat dari buku catatan dan alat tulis yang sudah siap di atas meja masingmasing. Ketua kelas berdiri dan memberi komando kepada teman-temannya dengan mengucapkan salam panganjali umat "om swastyastu", kemudian guru dan peneliti menjawab salam mereka.

Guru terlebih dahulu mengisi jurnal dan mengecek kehadiran siswa. Semua siswa hadir pada saat itu. Guru memberikan apresiasi kepada siswa kelas VII.4, karena kelas tersebut tergolong kelas yang rajin dan jarang ada siswa yang tidak hadir. Seluruh siswa bertepuk tangan dan tidak ada ketegangan dalam ruangan. Melihat situasi kelas yang demikian, guru pun memulai pelajaran dengan menanyakan materi pelajaran yang sudah dipelajari pada pertemuan sebelumnya. Seluruh siswa serentak menjawab bahwa materi pembelajaran sebelumnya yaitu Fabel. Guru pun membenarkan jawaban siswa. Selanjutnya, untuk mengetes ingatan siswa, guru bertanya mengenai pengertian Fabel. Sebagian siswa tampak mengacungkan tangan. Guru pun menunjuk siswa bernama Wahyu untuk menjawab. Menurut Wahyu, fabel adalah cerita anakanak. Guru membenarkan jawaban Wahyu sembari memberikan penguatan. Guru kembali memberikan kesempatan kepada siswa lain yang ingin mencoba memberikan pengertian mengenai fabel. Rizky nampak mengacungkan tangan dan guru langsung memberikan Rizky kesempatan untuk berbicara. Menurut Rizky, "fabel merupakan cerita binatang yang menyerupai manusia." Guru membenarkan jawaban Rizky dan memberikan penguatan kepada Rizky. Kemudian guru kembali memberi kesempatan kepada siswa lain untuk berbicara. Seluruh siswa tampak diam. Melihat satu pun siswa tidak ada lagi yang mengacungkan tangan, guru pun menyimpulkan kedua pendapat siswa dan menambahkan mengenai pengertian fabel yaitu "Fabel adalah cerita yang menceritakan kehdupan hewan yang menyerupai manusia yang mengandung pesan moral."

Memasuki kegiatan inti, guru kembali mengingatkan siswa tentang kelompok yang akan tampil untuk bermain peran di depan kelas. Suasana kelas menjadi tegang. Semua siswa tampak mempersiapkan diri untuk tampil. Guru memberikan waktu 15 menit untuk latihan di kelas tapi tidak boleh ribut. Tidak lupa guru menyampaikan kepada siswa, kelompok terbaik akan diberikan penghargaan. Penghargaan berupa nilai plus.

Guru memberikan kesempatan kepada siswa, mengenai kelompok yang akan tampil terlebih dahulu untuk bermain peran. Semua siswa nampak tegang. Akhirnya kelompok pertama yang memutuskan untuk tampil terlebih dahulu ke depan kelas. Kelompok pertama terdiri atas 5 orang yaitu Ditha, Dian, Juli, Andika dan Shelo. Mereka menampilkan teks fabel yang berjudul "Semua Istimewa". Pertama yang mereka 
lakukan menghaturkan panganjali umat "om swastyastu" lalu, salah satu dari mereka yaitu Ditha memperkenalkan anggota kelompoknya diantaranya ada Dian, Juli, Andika dan shelo. Setelah itu salah satu dari mereka membacakan narasi yaitu Dian. Di dalam cerita tersebut namanama tokohnya yaitu, Katak, semut, Ikan dan Burung. Ditha memerankan tokoh semut, Juli memerankan tokoh ikan, Andika memerankan tokoh Katak dan Shelo memerankan tokoh Burung. Di dalam cerita ini tokoh katak sangat sombong, tokoh semut rendah hati, tokoh ikan juga rendah hati yang selalu di lecehkan oleh Katak, dan yang terakhir tokoh Burung ini sangat bijak. Kelompok satu mulai memerankan setiap tokoh yang ada di cerita Fabel ini, dalam memerankan tokoh ikan Juli terlihat sangat menghayati. Akan tetapi tokoh yang diperankan Andika sebagai katak masih terlihat sangat grogi. Tokoh yang diperankan Shelo yaitu menjadi burung sangatlah bagus karena adegan Shelo tersebut sangat cocok menjadi orang yang bijak. Tokoh semut diperankan oleh ditha dalam memerankan tokoh semut Ditha masih sedikit grogi. Setelah itu kelompok satu mengucapkan "Om Santih, Santih, Santih Om".

Selanjutnya kelompok dua. Kelompok dua terdiri atas 5 orang yaitu Novia, Diah, Andre, Rizky, dan Wahyu. Mereka menampilkan teks fabel yang berjudul "Semua Istimewa". Pertama yang mereka lakukan menghaturkan panganjali umat "om swastyastu" lalu, salah satu dari mereka yaitu Wahyu memperkenalkan anggota kelompoknya diantaranya Novia, Diah, Andre dan Rizky. Setelah itu, salah satu dari mereka membacakan narasi yaitu Wahyu . Di dalam cerita tersebut namanama tokohnya yaitu, Katak, Semut, Ikan dan Burung. Novia memerankan tokoh Katak yang sangat angkuh dalam memerankan tokoh ini Novia nampak seperti orang yang paling sombong terhadap teman-temannya. Novia sangat bagus dalam memerankan tokoh Katak. Diah memerankan tokoh semut, dalam memerankan tokoh semut ini diah sangat menghayati sekali sehingga teman-teman di kelasnya bertepuk tangan. Andre memerankan tokoh ikan, dalam memerankan tokoh tersebut Andre juga terlihat sangat menghayati. Yang terakhir, Rizky memerankan tokoh burung, dalam memerankan tokoh tersebut Rizky terlihat sangat Bijak sehingga teman-teman di kelas bertepuk tangan dan tertawa. Suasana kelas saat itu sangat menyenangkan. Setelah itu, kelompok dua mengucapkan "Om Santih, Santih, Santih Om"

Selanjutnya kelompok tiga. Kelompok tiga terdiri atas 5 orang, yaitu Ari, Fendy, Andi, Satiawan, dan Pradnya. Mereka menampilkan teks fabel yang berjudul "Semua Istimewa". Pertama yang mereka lakukan menghaturkan panganjali umat "om swastyastu" lalu, salah satu dari mereka yaitu Ari memperkenalkan anggota kelompoknya diantaranya Fendy, Andi. Satiawan, dan Pradnya. Setelah itu salah satu dari mereka membacakan narasi yaitu Ari. Di dalam cerita tersebut nama-nama tokohnya yaitu, Katak, Semut, Ikan dan Burung. Fendy memerankan tokoh Katak yang sangat angkuh dalam memerankan tokoh ini Fendy nampak sangat tegang sehingga saat berbicara terlihat grogi. Andi memerankan tokoh Semut, dalam memerankan tokoh tersebut Andi terlihat sangat grogi saat berbicara kepada Katak. Satiawan memerankan tokoh Ikan, dalam memerankan tokoh tersebut Satiawan terlihat sangat menghayati perannya. Pradnya memerankan tokoh Burung, dalam memerankan tokoh tersebut Pradnya terlihat sangat tidak percaya diri dengan perannya sehigga Pradnya grogi. Setelah itu, kelompok satu mengucapkan "Om Santih, Santih, Santih Om". Penampilan kelompok tiga telah usai , semua temanteman tampak bertepuk tangan.

Selanjutnya, respons siswa terhadap penerapan metode bermain peran siswa tergolong sangat positif.(27-30). Kendala pertama yang dialami guru adalah kesiapan siswa kurang, Kendala kedua yang dialami guru adalah pembelajaran Bahasa Indonesia kurang diminati siswa karena merupakan pembelajaran yang membosankan. Kendala ketiga yang dialami guru adalah susahnya guru 
memberikan motivasi kepada beberapa siswa.

Pembahasan hasil penelitian ini difokuskan pada temuan tentang pembelajaran fabel dalam bermain peran oleh guru meliputi (1) penerapan metode bermain peran pada pembelajaran bahasa indonesia materi fabel (2) respons siswa terhadap metode bermain peran, kendala guru dalam menggunakan metode bermain peran. Temuan-temuan tersebut diuraikan sebagai berikut.

Temuan pertama adalah aktivitas guru dan siswa dalam pembelajaran fabel menggunakan metode bermain peran. Guru yang dijadikan objek penelitian adalah Made Ratna Pratiwi,S.Pd. Kelas yang diteliti adalah kelas VII 4. Kelas tersebut berjumlah 29 orang. Yang pertama ditempuh oleh guru dalam menerapkan metode bermain peran ialah (1) kegiatan awal (2) kegiatan inti, dan (3) kegiatan penutup. Pada pertemuan pertama siswa dikenalkan teks fabel oleh guru mulai dari pengertian, dan ciri-ciri teks fabel. Guru membagi jumlah siswa menjadi beberapa kelompok yang akan dipergunakan dipertemuan kedua.

Pada pertemuan kedua barulah siwa mempraktikkan metode bermain peran. Pada kegiatan awal guru dan peserta didik mengucapkan salam. Setelah itu guru mengecek kehadiran siswa dan mengamati keberihan kelas. Kemudian guru melakukan apersepsi dengan menanyakan kembali pembelajaran pada pertemuan pertama. Guru memberikan motivasi kepada siswa setelah itu menyampaikan kompetensi dasar, indikator dan materi yang akan diajarkan. Pada kegiatan inti, guru ,membagi peserta didik menjadi enam kelompok sesuai dengan hasil pembagian pada pertemuan pertama. Guru meminta peserta didik duduk sesuai dengan kelompoknya masing-masing. Guru meminta peserta didik mempelajari teks fabel yang akan diperankan. Guru memberikan kesempatan kepada peserta didik untuk bertanya tentang teks yang akan diperankan. Siswa tampil didepan kelas untuk bermain peran. Metode bermain peran diaplikasikan pada saat siswa dan guru bersama-sama mengikuti kegiatan pembelajaran fabel. Metode bermain peran menurut Sudjana,(2005) adalah metode pembelajaran yang menekankan pada kemampuan peserta didik untuk memerankan status dan fungsi pihak-pihak lain yang terdapat pada kehidupan nyata. Dengan bermain peran ini diharapkan para peserta didik dapat memeroleh pengalaman yang diperankan oleh pihak-pihak lain. Hal itu disebabkan metode pembelajaran bermain peran dapat digunakan pula untuk merangsang pendapat peserta didik dan menemukan kesepakatan bersama,ketepatan, kekurangan dan pengembangan peranperan yang dialami atau diamati. Sejalan dengan hal tersebut guru juga sudah memilih dan membuat metode yang tepat serta menggunakan metode tersebut secara nyata dalam pembelajaran. Metode ini disediakan oleh guru dapat diterima dan dipahami dengan baik oleh siswa konteks belajar yang dilakukan saat pembelajaran berlangsung yaitu siswa mendsikusikan metode yang diberikan, memahami metode yang diberikan. Rangkaian aktivitas tersebut mampu dilaksanakan secara tepat, baik,dan efisien.

Metode bermain peran dipilih peneliti untuk diterapkan di kelas VII 4 karena peneliti mengetahui proses belajar mengajar jika menggunakan metode bermain peran. Sejalan dengan pendapat Hasan,(1996) ialah melalui metode pembelajaran bermain peran siswa diajak untuk belajar memecahkan masalah pribadi, dengan menggunakan bantuan kelompok sosial yang anggotanya terdiri atas teman-temannya sendiri. Dengan kata lain, metode pembelajaran bermain peran berupaya membantu individu melalui proses kelompok sosial. Melalui metode pembelajaran bermain peran, para siswa mencoba mengeksploitasi masalahmasalah hubungan antar manusia dengan cara memperagakannya.

Setelah itu, tidak lupa guru menyampaikan kepada siswa, kelompok terbaik akan diberikan penghargaan. Penghargaan berupa nilai plus. Sejalan dengan pendapat Erwin ( 2017 ) bahwa sebaiknya kita memberikan penghargaan bagi peserta didik dengan pujian 
pemberian nilai yang lebih , ataupun ucapan terima kasih. Maka dari itu, alangkah baiknya kita sebagai guru harus memberikan penghargaan supaya menarik minat belajar siswa.

Temuan kedua dalam penelitian ini adalah siswa menjadi sangat senang dan aktif mengikuti pembelajaran fabel. Hal tersebut dapat dilihat dari nilai rata-rata respons yang diberikan oleh siswa dalam pembelajaran ini.Sebagian besar siswa memberikan respons sangat positif terhadap tindakan yang dilakukan oleh guru dalam pembelajaran yakni 27,73 (sangat positif). Siswa merasa senang melakukan kegiatan pembelajaran karena divariasikan dengan penerapan metode bermain peran. Berdasarkan pemaparan di atas, penerapan metode bermain peran yang digunakan guru dalam pembelajaran fabel dapat memperoleh hasil yang baik. Hal itu terlihat adanya rata-rata skor siswa dalam pembelajaran fabel dengan menggunakan metode bermain peran yang tergolong sangat baik. Di samping memperoleh hasil yang baik dalam pembelajaran fabel dengan menggunakan metode bermain peran, penerapan metode bermain peran juga memperoleh respons yang sangat positif terhadap penerapan metode bermain peran.

Temuan ini sejalan dengan penelitian yang dilakukan oleh I Komang Dodik Muliarto pada tahun 2010. Dodik menunjukkan bahwa terkait dengan tangggapan siswa kelas XI IPBI Sukawati ialah sangat positif. Berdasarkan hal tersebut, penerapan metode bemain peran yang digunakan guru dalam pembelajaran Fabel dapat memeroleh hasil yang baik. Hal itu terlihat adanya rata-rata skor siswa dalam pembelajaran fabel menggunakan metode bermain peran tergolong sangat baik. Di samping memeroleh hasil yang baik,penerapan metode bermain peran juga memperoleh respon yang sangat positif terhadap pembelajaran Fabel dengan menggunakan Metode Bermain Peran.

Temuan ketiga kendala guru dalam menggunakan metode bermain peran pada pembelajaran bahasa indonesia materi fabel di kelas VII 4 SMP N 2 Singaraja yang diperoleh dengan metode wawancara.
Berdasarkan hasil wawancara dengan guru pengajar di kelas VII 4, ada tiga kendala yang dialami guru dalam mengajar.

Kendala pertama yang dialami guru adalah kesiapan siswa kurang, sehingga pada saat memerankan tokoh dalam cerita fabel ini ada beberapa siswa yang tidak mau berbicara karena malu. Oleh karena itu, guru berusaha supaya beberapa siswa tampil dengan cara memberikan penghargaan kepada siswa. Terbukti berdasarkan hasil wawancara peneliti dengan siswa, kendala yang dialami sebagian kecil siswa berupa keterbatasan siswa itu sendiri, yaitu tidak terbiasa berbicara di depan umum. Seperti yang telah diketahui bahwa siswa yang tidak terbiasa berbicara di depan umum akan merasa grogi ketika dituntut untuk berbicara. Selain itu, berbicara juga merupakan suatu keterampilan yang membutuhkan latihan dan kecakapan. Memang, jika siswa tidak terbiasa melatih keterampilan berbicara, maka akan menemui kesulitan ketika dituntut berbicara di hadapan banyak orang.

Kendala kedua yang dialami guru adalah pembelajaran Bahasa Indonesia kurang diminati siswa karena merupakan pembelajaran yang membosankan. Apalagi pada pembelajaran di waktu siang. Oleh karena itu, guru mengalami kesulitan dalam menarik minat dan semangat siswa untuk belajar bahasa Indonesia, terkhususnya dalam bermain peran Teks Fabel. Sejalan dengan pendapat Erwin (2017), hal ini biasanya terjadi pada peserta didik mengalami kekurangan istirahat, karena padatnya kegiatan yang harus mereka ikuti. Terbukti saat melakukan wawancara siswa yang sering mengantuk. Sebab kegiatan siswa sangat padat. Sehingga pada saat proses pembelajaran berlangsung siswa mengantuk dan pembelajaran akan terasa membosankan.

Kendala ketiga yang dialami guru adalah susahnya guru memberikan motivasi kepada beberapa siswa yang tidak suka pembelajaran sastra, salah satunya saat materi Fabel. Kendala yang bersumber dari siswa karena kurangnya antusias siswa ketika mengikuti kegiatan belajar dan keterbatasan kemampuan siswa. Hal itu 
senada dengan pandangan Hadisoeparto (2003) bahwa kendala yang disebabkan oleh siswa bisa terjadi apabila dalam proses belajar mengajar siswa tidak berantusias dan merasa kurang termotivasi mengikuti pembelajaran yang dilaksanakan oleh guru. Siswa yang kurang mampu mengikuti kegiatan belajar dengan maksimal, akan menghambat tujuan pembelajaran. Dengan demikian, pada pembelajaran selanjutnya terutama dalam pembelajaran Fabel, guru harus lebih intens membimbing siswa yang memiliki kemampuan terbatas, agar seluruh siswa memiliki motivasi belajar yang tinggi.

\section{SIMPULAN DAN SARAN}

Ada tiga simpulan yang dapat peneliti ambil berdasarkan rumusan masalah yang telah ditetapkan. Simpulan tersebut adalah:

Hasil observasi yang dilakukan peneliti mengenai penggunaan metode bermain peran dalam pembelajaran fabel di kelas VII 4 SMP Negeri 2 Singaraja, penerapan metode bermain peran sangat efektif dan bermanfaat dalam pembelajaran fabel. Hal tersebut dapat dilihat berdasarkan pengamatan yang dilakukan peneliti, yaitu metode bermain peran yang digunakan dalam pembelajaran fabel melatih keterampilan berbicara siswa, sehingga siswa dapat memainkan peran dengan baik. Metode ini bertujuan untuk memotivasi siswa menarik minat dan perhatian siswa, memberikan kesempatan kepada siswa untuk mengeksplorasi situasi saat mengalami emosi, perbedaan pendapat, dan permasalahan dalam lingkungan hidup social anak, menarik siswa untuk bertanya, mengembangkan kemampuan komunikasi siswa, dan melatih siswa untuk berperan aktif dalam kehidupan nyata.

Setelah mengikuti pembelajaran
fabel dengan metode bermain peran
sebagian besar siswa merespons positif,
yakni merasa senang, tertantang, dan
tertarik. Hal tersebut disebabkan oleh
penggunaan metode bermain peran pada
pembelajaran fabel dapat melatih
keterampilan berbicara siswa dan
memberikan pengalaman dalam

memainkan peran. Di sisi lain, sebagian kecil siswa merasa kurang senang dan kurang tertarik terhadap penggunaan metode bermain peran dalam pembelajaran fabel karena keterbatasan siswa itu sendiri, yaitu tidak terbiasa berbicara di depan umum dan tidak terbiasa melatih keterampilan berbicara.

Kendala guru dalam menggunakan bermain peran pada pembelajaran fabel di kelas VII 4 SMP Negeri 2 Singaraja, yaitu dilihat dari kesiapan siswa kurang, pembelajaran abel yang membosankan, dan kurangnya motivasu guru terhadap siswa.. Dari segi siswa, sebagian kecil siswa kurang atau belum memahami memainkan peran, kurangnya minat membaca dan pengalaman siswa.

Penggunaan metode bermain peran sudah sangat efektif dan bermanfaat dalam pembelajaran fabel, yaitu metode bermain peran yang digunakan dalam pembelajaran fabel menggunakan metode bermain peran untuk melatih keterampilan berbicara, sehingga siswa percaya diri dalam memainkan peran. Oleh karena itu, disarankan kepada guru Bahasa Indonesia tersebut agar mempertahankan pembelajaran fabel dengan menggunakan metode bermain peran dalam pembelajaran fabel. Disarankan juga kepada guru Bahasa Indonesia yang lain agar mencoba menggunakan metode bermain peran dalam kegiatan belajar mengajar di kelas, karena metode bermain peran bermanfaat untuk melatih keterampilan berbicara siswa. Setelah mengikuti pembelajaran fabel dengan metode bermain peran sebagian besar siswa merasa senang, tertantang, dan tertarik. Di sisi lain, sebagian kecil siswa merasa kurang senang dan kurang tertarik mengikuti penggunaan metode bermain peran dalam pembelajaran debat karena keterbatasan siswa itu sendiri. Oleh karena itu, disarankan kepada guru agar lebih memotivasi siswa yang kurang aktif.

Kendala guru dalam menggunakan metode bermain peran pada pembelajaran fabel di kelas VII 4 SMP Negeri 2 Singaraja yaitu dilihat dari kesiapan siswa kurang, pembelajaran bahasa Indonesia yang membosankan, dan kurangnya motivasi guru terhadap siswa. Oleh karena itu, 
disarankan kepada siswa agar lebih giat belajar dan berlatih di sekolah dan di luar sekolah.

\section{DAFTAR PUSTAKA}

Djamarah. 2008. Guru dan Anak Didik. Jakarta: Penerbit Rineka Cipta.

Hardisoeparto, A.2003. kesulitan belajar mengajar.Jakarta: Bina Aksara.

Hasan, S.N. 1996. Pendidikan IImu-ilmu Sosial Buku 1 dan 2. Bandung: Jurusan Pendidikan Sejarah Upi.

Sudjana, Nano. 2005. Dasar-dasar Proses Belajar Mengajar. Bandung: Sinar Baru.

Widiasworo.2017. Masalah-masalah Peserta Didik dalam Kelas dan Solusinya. Araska: hak cipta dilindungi undang-undang.

Zaini, Hisyam. 2008. Strategi Pembelajaran Aktif. Yogyakarta: Pustaka Insan Madani. 
